\title{
Effects of follicle size and electrolytes and glucose in maturation medium on nuclear maturation and developmental competence of bovine oocytes
}

\author{
Hisataka Iwata, Shu Hashimoto ${ }^{1}$, Mayuko Ohota, Koji Kimura ${ }^{2}$, Kenichi Shibano ${ }^{3}$ and \\ Masashi Miyake
}

Kobe Minori Public Corporation, Kobe 651-2204, Japan, ${ }^{1}$ YS New Technology Institute Inc., Tochigi 329-0512, Japan, ${ }^{2}$ National Institute of Livestock and Grassland Science, Tochigi 329-2793, Japan, ${ }^{3}$ Prefectural Federation of Agricultural Mutual Aid Association, Hyogo 651-2272, Japan and ${ }^{4}$ Graduate School of Science and Technology, Kobe 657-8501, Japan

Correspondence should be addressed to H Iwata, West Agricultural Office of Kobe City (Seishin-Bunka-Center), 1058 Jyunna Ikawadani-Chou Nishi-ku, Kobe City, 651-2124 Japan; E-mail: QYM04636@nifty.com

\begin{abstract}
The concentrations of electrolytes ( $\mathrm{Na}, \mathrm{K}, \mathrm{Cl}, \mathrm{Mg}$ and $\mathrm{Ca}$ ) and glucose in small follicle (SF) follicular fluid (SFF) and large follicle (LF) follicular fluid (LFF) from slaughterhouse-derived ovaries were studied. Oocytes were matured in medium based on synthetic oviductal fluid. The effects of various concentrations of electrolytes ( $\mathrm{Na}, \mathrm{K}, \mathrm{Ca}$ and $\mathrm{Mg}$ ) and glucose in the maturation medium on the progression of nuclear maturation and subsequent development were also studied. $K$ in SFF was significantly greater than that in LFF. The Mg concentration in follicular fluid (FF) is $2.0-2.3 \mathrm{mM}$, which is greater than the concentration present in medium generally used for culture. The glucose concentration in FF is about 3.5-3.9 mM and rapidly decreases during the preservation of ovaries. LF oocytes resumed nuclear maturation and progressed to the M2 stage significantly faster than those collected from SF oocytes. In addition, more LF oocytes developed to blastocysts than did SF oocytes. Changing the $\mathrm{Na} / \mathrm{K}$ ratio in the maturation medium from 16 to 24 did not affect either the progression of nuclear maturation or the rate of development. A low concentration of $\mathrm{Mg}(0.5 \mathrm{mM})$ combined with a low Ca concentration $(0.5 \mathrm{mM})$ inhibited the rate of development, but did not affect the progression of nuclear maturation. On the other hand, increasing the $\mathrm{Mg}$ concentration to $2.0 \mathrm{mM}$ from $0.5 \mathrm{mM}$ hastened the progression of nuclear maturation and improved the rate of blastulation, irrespective of the Ca concentration. The progression of nuclear maturation was faster and the rate of development was greater with $5.56 \mathrm{mM}$ glucose than with $1.5 \mathrm{mM}$ glucose. The difference in time needed to progress to $\mathrm{M} 2$ among the experiment was about $2-3 \mathrm{~h}$. Therefore, prolonging the maturation periods from 21 to $24 \mathrm{~h}$ did not change the rate of development. Our results show that the concentrations of $\mathrm{Mg}$ and glucose in the maturation medium and the follicle size enveloping the oocyte affect the progression of nuclear maturation and subsequent development. The time requirement for oocytes to reach $\mathrm{M} 2$ is strongly related to the developmental competence of the oocytes.

Reproduction (2004) 127 159-164
\end{abstract}

\section{Introduction}

In vitro embryo development is known to be highly affected by oocyte quality. In the cow, growth of the oocyte is almost completed when its enveloping follicle reaches a diameter of $3 \mathrm{~mm}$ (Fair et al. 1995). Many studies have shown that oocytes collected from large diameter follicles (LFs) are more likely to develop to the blastocyst stage than oocytes collected from small diameter follicles (SFs) (Pavlok et al. 1992, Lonergan et al. 1994, Blondin \& Sirard 1995, Yang et al. 1998, Hagemann 1999, Hagemann et al. 1999, Hendriksen et al.
2000) and these reports indicate that the prematuration of an oocyte which occurs during follicle growth is essential for subsequent development. Although some oocytes collected from SFs and LFs are already competent to develop in vitro into a blastocyst that can result in vital offspring after transfer, additional but essential development occurs in vivo during subsequent follicle growth, and this final maturation process (from luteinizing hormone surge to ovulation) strongly affects the developmental competence of oocytes (Blondin et al. 1997, Dieleman et al. 2002). These reports indicate that culture conditions that are 
usually used for in vitro maturation (IVM) of bovine oocytes are suboptimal and that it is important to optimize the conditions for maturation to produce blastocysts more efficiently. The medium that is usually used for IVM is TCM-199 or synthetic oviductal fluid (SOF) (Takahashi \& First 1992). Few studies have examined the effects of changing the basic elemental contents of the maturation medium.

The developmental rate and nuclear maturation are used as simple indexes of the ability of oocytes to undergo subsequent development. Dominko \& First (1997) reported that the time it takes oocytes to resume meiosis and progress to $\mathrm{M} 2$ arrest is important for determining the subsequent developmental competence of oocytes. However, few reports have examined the relationship between the developmental competence of oocytes and the progression of nuclear maturation. In this study, the concentrations of $\mathrm{Na}, \mathrm{K}, \mathrm{Cl}, \mathrm{Mg}, \mathrm{Ca}$ and glucose in the follicular fluid (FF) from LFs (LFF) and the FF from SFs (SFF) were measured and then the effects of follicle size and electrolyte and glucose concentrations in the maturation medium on both the progression of nuclear maturation and the rate of development were studied.

\section{Materials and Methods}

\section{IVM, in vitro fertilization (IVF) and in vitro culture (IVC)}

Bovine ovaries were collected from carcasses at a slaughterhouse. They were preserved in physiological saline at approximately $35^{\circ} \mathrm{C}$ and transported to the laboratory within $3 \mathrm{~h}$. Cumulus-oocyte complexes (COCs) were aspirated from small antral follicles (3-6 $\mathrm{mm}$ in diameter) or large antral follicles $(6-12 \mathrm{~mm}$ in diameter) using a $20-\mathrm{G}$ needle connected to a $10 \mathrm{ml}$ syringe. COCs surrounded by compact and thick cumulus cells were randomly selected and cultured in a $100 \mu \mathrm{l}$ drop of maturation medium (15 oocytes/drop) under paraffin oil at $39^{\circ} \mathrm{C}$ in an atmosphere of $5 \% \mathrm{CO}_{2}$ in air with maximum humidity. The media used for IVM, IVF and IVC were based on SOF supplemented with $5 \mathrm{mM}$ taurine and $1 \mathrm{mM}$ glutamine (Nacalai Tesque, Kyoto, Japan) and the medium was modified for each usage as described in Table 1. FF was collected from pooled small or large antral follicles from five pairs of ovaries that were stored for $1-2 \mathrm{~h}$ at $35^{\circ} \mathrm{C}$. After centrifugation, each FF was transferred to a test tube and stored at $-35^{\circ} \mathrm{C}$ until examination.

\section{IVF}

Frozen-thawed $\left(37^{\circ} \mathrm{C}\right)$ semen from a Japanese Black bull was washed with a 45-60\% discontinuous Percoll (Pharmacia Co., Ltd, Uppsala, Sweden) gradient solution by centrifugation $(500 \mathrm{~g})$ for $10 \mathrm{~min}$. After centrifugation, the semen was diluted to a concentration of $2 \times 10^{6} \mathrm{sperm} / \mathrm{ml}$ with IVF medium. Oocytes cultured for $21 \mathrm{~h}$ in maturation medium were washed with IVF medium and were
Table 1 Composition of control SOF used for IVM, IVF and IVC.

\begin{tabular}{lccccc}
\hline Ingredient & Source & IVM & IVF & IVC1 $^{*}$ & IVC2 $^{* *}$ \\
\hline Glucose $(\mathrm{mM})$ & - & 5.56 & - & 1 & 1.5 \\
Pyruvic acid $(\mathrm{mM})$ & $\mathrm{a}$ & 0.5 & 0.5 & 0.5 & 0.5 \\
Na lactate & $\mathrm{a}$ & - & + & + & + \\
NEAA & $\mathrm{b}$ & + & - & + & + \\
EAA & $\mathrm{c}$ & + & - & - & + \\
Fetal calf serum (\%) & $\mathrm{d}$ & 10 & - & 1 & 5 \\
BSA(mg/ml) & $\mathrm{e}$ & - & 7 & - & - \\
Heparin (units/ml) & $\mathrm{a}$ & - & 10 & - & - \\
\hline
\end{tabular}

* In vitro culture medium from $18-48 \mathrm{~h}$ after fertilization.

** In vitro culture medium from 48-196 h after fertilization.

a, Sigma Chemical Co., St. Louis, MO, USA.

b, Non-essential amino acids (NEAA) basal Eagle's medium.

c, Essential amino acids (EAA) Eagle's minimal essential medium.

d, Gibco-BRL, Rockville, MD, USA.

e, Nacalai Chemicals co., Tokyo, Japan.

transferred to $100 \mu \mathrm{l}$ drops of sperm suspension for fertilization (15 oocytes/drop), and then cultured for $18 \mathrm{~h}$. Incubation was carried out at $39{ }^{\circ} \mathrm{C}$ in an atmosphere of $5 \%$ $\mathrm{CO}_{2}$ in air with maximum humidity.

\section{IVC}

Eighteen hours after fertilization, oocytes were denuded by vortexing (30s) and cultured in a $100 \mu \mathrm{l}$ drop of IVC1 medium (Table 1) (15 zygotes/drop). Forty-eight hours after fertilization, the number of cleaved embryos (greater than four cells) was counted and these cleaved embryos were transported to a $100 \mu$ l drop of IVC2 medium. Fortyfive oocytes were taken for experiment and each experiment was repeated four times and the rate of blastulation was assessed at days 7 and 8 after fertilization. Embryos were cultured at $39^{\circ} \mathrm{C}$ in an atmosphere of $5 \% \mathrm{CO}_{2}, 5 \%$ $\mathrm{O}_{2}$ and $90 \% \quad \mathrm{~N}_{2}$ with maximum humidity. To study nuclear maturation, about 60 oocytes were randomly selected for each experimental group. Oocytes that had been cultured for 5,18 and $21 \mathrm{~h}$ in the IVM medium were denuded by treatment with $0.2 \%$ hyaluronidase for $6 \mathrm{~min}$ followed by vortexing for $6 \mathrm{~min}$. The denuded oocytes were mounted on a slide, fixed with acetic acid/ethanol $(1: 3 \mathrm{v} / \mathrm{v})$ for $24 \mathrm{~h}$ and stained with aceto-orcein before examination under a phase-contrast microscope $(x 400)$.

\section{Experimental design}

In experiment 1, FF was thawed just before examination. The concentrations of $\mathrm{Mg}, \mathrm{Ca}$ and glucose were measured with an automatic analyzer (Accute TBA-40 FR; Toshiba Co., Tokyo, Japan) and the concentration of $\mathrm{Na}, \mathrm{K}$ and $\mathrm{Cl}$ were measured using a Spotchem-SE electrolyte analyzer (Arkray Inc., Kyoto, Japan).

In experiment 2, the effect of follicle size on the developmental competence and the nuclear maturation of oocytes was studied.

In experiment 3, the effects of $\mathrm{Na}$ and $\mathrm{K}$ concentrations in the maturation medium on developmental competence and nuclear maturation were studied. Based on the results 
Table 2 Elemental contents in FF collected from SFs and LFs $(n=7)$.

\begin{tabular}{|c|c|c|}
\hline \multirow[b]{2}{*}{ Element } & \multicolumn{2}{|c|}{ Concentration (mM) } \\
\hline & SFs & LFs \\
\hline $\mathrm{Na}$ & $127 \pm 9.6$ & $128 \pm 10.8$ \\
\hline K & $9.7 \pm 1.5^{\mathrm{a}}$ & $6.3 \pm 0.8$ \\
\hline $\mathrm{Cl}$ & $100 \pm 6.3$ & $99.4 \pm 6.1$ \\
\hline Mg & $2.3 \pm 0.2$ & $2 \pm 0.5$ \\
\hline $\mathrm{Ca}$ & $1.9 \pm 0.2$ & $2.1 \pm 0.1$ \\
\hline Glucose & $1.9 \pm 0.2^{\mathrm{a}}$ & $2.9 \pm 0.3$ \\
\hline Glucose* & $3.5 \pm 0.5$ & $3.9 \pm 0.4$ \\
\hline
\end{tabular}

${ }^{\text {a }}$ ifferent superscripts within the same row differ significantly $(P<0.05)$.

*FFs were collected just after ovary collection.

of experiment $1, \mathrm{Na}$ and $\mathrm{K}$ concentrations were adjusted to 133 and $5.4 \mathrm{mM}(\mathrm{Na} / \mathrm{K}: 24)$ in order to resemble the concentrations present in TCM-199, or 133 and $8.3 \mathrm{mM}$ $(\mathrm{Na} / \mathrm{K}: 15.9)$ in order to resemble the concentrations present in SOF.

In experiment 4 , the effects of two different concentrations of $\mathrm{Mg}(0.5$ and $2 \mathrm{mM})$ and two different concentrations of $\mathrm{Ca}(0.5$ and $1.8 \mathrm{mM})$ in the maturation medium on the developmental competence and the nuclear maturation were examined in a $2 \times 2$ factorial design. Concentrations of $\mathrm{Mg}$ and $\mathrm{Ca}$ in the IVM medium were adjusted to 0.5 and $1.8 \mathrm{mM}, 0.5$ and $0.5 \mathrm{mM}, 2$ and $1.8 \mathrm{mM}$, and 2 and $0.5 \mathrm{mM}$.

In experiment 5, the effect of two glucose concentrations in the maturation medium $(1.5$ or $5.56 \mathrm{mM})$ on developmental competence and nuclear maturation were studied. Based on the glucose concentration measured in experiment 1, 1.5 and $5.56 \mathrm{mM}$ were selected as the low and high concentrations.
In experiment 6, the maturation periods of the experimental groups in which the progression of nuclear maturation was slow were prolonged from 21 to $24 \mathrm{~h}$. The culture medium was IVM medium containing 1.5 or $5.56 \mathrm{mM}$ glucose. And then the effect of the maturation period on the developmental competence of the oocyte was studied.

\section{Statistical analysis}

To analyze the electrolytes and glucose concentrations in FF and the rate of blastulation, the frequency of dates were compared using Fisher's protected least significant difference test followed by ANOVA. All developmental data were subjected to an arcsine transformation before statistical analysis. To analyze the progression of nuclear maturation, data were compared by a chi-square test. $P$ values less than 0.05 were considered to be significant.

\section{Results}

The concentrations of electrolytes and glucose in FF are shown in Table 2 . The $\mathrm{K}$ concentration was significantly greater in SFF than in LFF. Glucose concentration in SFF $(1.9 \mathrm{mM})$ was significantly less than that in $\operatorname{LFF}(2.9 \mathrm{mM})$, although when the FFs were collected just after slaughter, the concentrations were the same. The concentration of $\mathrm{Mg}$ in FF was 2-2.3 $\mathrm{mM}$, which was greater than the concentrations in SOF (0.5 mM) or TCM-199 (0.8 mM).

In experiment 2, oocytes collected from LFs resumed nuclear maturation and progressed to the $M 2$ stage significantly faster than SF oocytes (Table 3). However, at the end of the maturation period, the developmental rate of oocytes to the M2 stage was the same. In addition, more of the LF oocytes developed to the blastocyst stage than did

Table 3 The progression of meiotic maturation and developmental rate of oocytes collected from LFs or SFs.

\begin{tabular}{|c|c|c|c|c|c|c|c|}
\hline \multirow[b]{2}{*}{$\begin{array}{l}\text { Follicle } \\
\text { size }\end{array}$} & \multicolumn{3}{|c|}{ Hours after culture } & \multirow[b]{2}{*}{$\begin{array}{c}\text { No. of } \\
\text { oocytes examined }\end{array}$} & \multicolumn{3}{|c|}{ Rate $(\%)$ of development } \\
\hline & $\begin{array}{c}5 \mathrm{~h} \\
(\text { no. of oocytes at GV }(\%))\end{array}$ & $\begin{array}{c}18 \mathrm{~h} \\
\text { (no. of } \mathrm{M} 2(\%))\end{array}$ & $\begin{array}{c}21 \mathrm{~h} \\
\text { (no. of } \mathrm{M} 2(\%))\end{array}$ & & $\begin{array}{c}\text { Day } 2 \\
\text { (cleaved }(>4 \text { cells }))\end{array}$ & $\begin{array}{c}\text { Day } 7^{*} \\
\text { (blastocyst) }\end{array}$ & $\begin{array}{c}\text { Day } 8^{*} \\
\text { (blastocyst) }\end{array}$ \\
\hline Small & $32 / 60(53)$ & $22 / 65(34)$ & $53 / 61(87)$ & 180 & 66 & 33 & 37 \\
\hline Large & $14 / 60(23)^{a}$ & $40 / 62(65)^{a}$ & $53 / 60(88)$ & 60 & $82^{\mathrm{a}}$ & $43^{a}$ & $47^{\mathrm{a}}$ \\
\hline
\end{tabular}

GV, geminal vesicle stage.

${ }^{a}$ Different superscripts within the same column differ significantly $(P<0.05)$.

*Days after insemination.

Table 4 The progression of meiotic maturation and developmental rate of oocytes cultured in medium containing various $\mathrm{Na} / \mathrm{K}$ ratios.

\begin{tabular}{|c|c|c|c|c|c|c|c|}
\hline \multirow[b]{2}{*}{$\begin{array}{l}\text { Ratio of } \\
\mathrm{Na} / \mathrm{K}\end{array}$} & \multicolumn{3}{|c|}{ Hours after culture } & \multirow[b]{2}{*}{$\begin{array}{c}\text { No. of } \\
\text { oocytes examined }\end{array}$} & \multicolumn{3}{|c|}{ Rate $(\%)$ of development } \\
\hline & $\begin{array}{c}5 \mathrm{~h} \\
\text { (no. of oocytes at GV }(\%) \text { ) }\end{array}$ & $\begin{array}{c}18 \mathrm{~h} \\
\text { (no. of } \mathrm{M} 2(\%) \text { ) }\end{array}$ & $\begin{array}{c}21 \mathrm{~h} \\
\text { (no. of } \mathrm{M} 2(\%))\end{array}$ & & $\begin{array}{c}\text { Day } 2^{*} \\
\text { (cleaved }(>4 \text { cells }))\end{array}$ & $\begin{array}{c}\text { Day } 7^{*} \\
\text { (blastocyst) }\end{array}$ & $\begin{array}{c}\text { Day } 8^{*} \\
\text { (blastocyst) }\end{array}$ \\
\hline 16 & $27 / 60(45)$ & $16 / 63(25)$ & 49/61 (80) & 180 & 67 & 21 & 26 \\
\hline 24 & $34 / 60$ (57) & $17 / 62(27)$ & $49 / 60(82)$ & 178 & 67 & 20 & 24 \\
\hline
\end{tabular}

GV, geminal vesicle stage.

*Days after insemination. 
Table 5 The progression of meiotic maturation and developmental rate of oocytes cultured in medium containing various concentrations of Mg and $\mathrm{Ca}$.

\begin{tabular}{|c|c|c|c|c|c|c|c|c|}
\hline \multirow[b]{2}{*}{$\underset{(\mathrm{mM})}{\mathbf{M g}}$} & \multirow[b]{2}{*}{$\begin{array}{c}\mathbf{C a} \\
(\mathrm{mM})\end{array}$} & \multicolumn{3}{|c|}{ Hours after culture } & \multirow[b]{2}{*}{$\begin{array}{c}\text { No.of } \\
\text { oocytes examined }\end{array}$} & \multicolumn{3}{|c|}{ Rate (\%) of development } \\
\hline & & $\begin{array}{c}5 \mathrm{~h} \\
\text { (no. of oocytes at GV (\%)) }\end{array}$ & $\begin{array}{c}18 \mathrm{~h} \\
(\text { no. of } \mathrm{M} 2(\%))\end{array}$ & $\begin{array}{c}21 \mathrm{~h} \\
(\text { no. of } \mathrm{M} 2(\%))\end{array}$ & & $\begin{array}{c}\text { Day } 2 * \\
(\text { cleaved }(>4 \text { cells }))\end{array}$ & $\begin{array}{c}\text { Day 7* } \\
\text { (blastocyst) }\end{array}$ & $\begin{array}{c}\text { Day 8* } \\
\text { (blastocyst) }\end{array}$ \\
\hline 0.5 & 1.8 & $27 / 60(45)^{\mathrm{a}}$ & $16 / 63(25)^{\mathrm{a}}$ & $49 / 60(82)$ & 179 & 77 & $22^{\mathrm{a}}$ & $29^{a}$ \\
\hline 0.5 & 0.5 & $28 / 60(47)^{\mathrm{a}}$ & $15 / 62(24)^{\mathrm{a}}$ & $49 / 60(82)$ & 180 & 72 & $20^{\mathrm{a}}$ & $21^{\mathrm{b}}$ \\
\hline 2 & 1.8 & $19 / 61(31)^{\mathrm{ab}}$ & $35 / 60(58)^{b}$ & $55 / 60(92)$ & 180 & 70 & $36^{\mathrm{b}}$ & $39^{c}$ \\
\hline 2 & 0.5 & $16 / 60(27)^{b}$ & $29 / 60(48)^{b}$ & $54 / 60(90)$ & 180 & 76 & $35^{\mathrm{b}}$ & $37^{\mathrm{ac}}$ \\
\hline
\end{tabular}

GV, geminal vesicle stage.

${ }^{a-c}$ Different superscripts within the same column differ significantly $(P<0.05)$.

Table 6 The progression of meiotic maturation and developmental rate of oocytes cultured in medium containing 5.56 or $1.5 \mathrm{mM}$ glucouse.

\begin{tabular}{|c|c|c|c|c|c|c|c|}
\hline \multirow[b]{2}{*}{$\begin{array}{l}\text { Glucose } \\
(\mathrm{mM})\end{array}$} & \multicolumn{3}{|c|}{ Hours after culture } & \multirow[b]{2}{*}{$\begin{array}{c}\text { No. of } \\
\text { oocytes examined }\end{array}$} & \multicolumn{3}{|c|}{ Rate (\%) of development } \\
\hline & $\begin{array}{c}5 \mathrm{~h} \\
\text { (no. of oocytes at GV (\%)) }\end{array}$ & $\begin{array}{c}18 \mathrm{~h} \\
(\text { no. of } \mathrm{M} 2(\%))\end{array}$ & $\begin{array}{c}21 \mathrm{~h} \\
\text { (no. of } \mathrm{M} 2(\%) \text { ) }\end{array}$ & & $\begin{array}{c}\text { Day } 2^{*} \\
\text { (cleaved }(>4 \text { cells }) \text { ) }\end{array}$ & $\begin{array}{c}\text { Day 7* } \\
\text { (blastocyst) }\end{array}$ & $\begin{array}{c}\text { Day } 8^{*} \\
\text { (blastocyst) }\end{array}$ \\
\hline 5.56 & $\begin{array}{l}14 / 60(23) \\
19 / 60(32)\end{array}$ & $22 / 62(35)$ & $52 / 60(87)$ & $\begin{array}{l}180 \\
180\end{array}$ & 66 & $\begin{array}{l}29 \\
22^{\mathrm{a}}\end{array}$ & $\begin{array}{l}35 \\
27^{\mathrm{a}}\end{array}$ \\
\hline
\end{tabular}

GV, geminal vesicle stage.

${ }^{a}$ Different superscripts within the same column differ significantly $(P<0.05)$.

the SF oocytes (Table 3). In experiment 3, the progression of nuclear maturation and the rate of development were the same for the two different $\mathrm{Na} / \mathrm{K}$ ratios (Table 4 ). In experiment 4, increasing the $\mathrm{Mg}$ concentration to $2 \mathrm{mM}$ from $0.5 \mathrm{mM}$ hastened the progression of meiotic maturation and improved the rate of blastulation, irrespective of the Ca concentration. On the other hand, low concentrations of $\mathrm{Mg}$ and $\mathrm{Ca}$ inhibited the rate of development, although the progression of nuclear maturation was the same (Table 5). In experiment 4, the progression of meiotic maturation was faster and the rate of development was greater (Table 6) with a high concentration of glucose $(5.56 \mathrm{mM})$ than with a low concentration of glucose $(1.5 \mathrm{mM})$, although the rates of $\mathrm{M} 2$ oocytes at the end of maturation were the same. In experiment 5, prolonging the maturation periods from 21 to $24 \mathrm{~h}$ did not affect the rate of development, regardless of the glucose concentration (Table 7).

Table 7 Developmental rate of oocytes cultured for 21 or $24 \mathrm{~h}$ in medium containing 5.56 or $1.5 \mathrm{mM}$ glucose.

\begin{tabular}{lcccccc}
\hline & & & & \multicolumn{2}{c}{$\begin{array}{c}\text { Rate (\%) of } \\
\text { blastocysts }\end{array}$} \\
\cline { 5 - 6 } $\begin{array}{c}\text { Glucose } \\
(\mathrm{mM})\end{array}$ & $\begin{array}{c}\text { Maturation } \\
\text { period }(\mathrm{h})\end{array}$ & $\begin{array}{c}\text { No. of } \\
\text { oocytes }\end{array}$ & $\begin{array}{c}\text { Rate (\%) } \\
\text { of cleaved* }\end{array}$ & Day7** & Day8** \\
\hline 1.5 & 21 & 180 & 68 & 23 & 26 \\
1.5 & 24 & 180 & 65 & 22 & 27 \\
5.56 & 21 & 180 & 76 & 31 & 35 \\
5.56 & 24 & 180 & 75 & 26 & 31 \\
\hline
\end{tabular}

$*>4$ cells.

**Days after insemination.

\section{Discussion}

Many studies have found that the blastocyst rate is greater for LF oocytes than for SF oocytes (Pavlok et al. 1992, Lonergan et al. 1994, Blondin \& Sirard 1995, Yang et al. 1998, Hagemann 1999, Hagemann et al. 1999, Hendriksen et al. 2000). This difference appears to be due to the different degree of prematuration of oocytes. Our results also showed that (i) the blastocyst rate was higher for LF oocytes than for SF oocytes; (ii) the progression of nuclear maturation occurred $2-3 \mathrm{~h}$ sooner for LF oocytes than for SF oocytes, although at the end of culture the rate of oocytes at the M2 stage was the same; and (iii) prolonging the maturation period of SF oocytes for $3 \mathrm{~h}$ did not change the rate of development (Table 7) These results show that high developmental competence may be associated with fast progression of nuclear maturation but not with the timing of fertilization. Therefore, only oocytes collected from SFs were used in the following experiments.

In this study, FF was collected from ovaries stored for $1-2 \mathrm{~h}$ as described above. During ovary preservation, the occlusion of blood flow reduced the oxygen and energy supply and placed ovaries under ischemic conditions. Under ischemic conditions, ATP depletion and the inability to re-establish high-energy phosphate damages cell function and causes cell death. In this study, the glucose concentration in SFF rapidly decreased during ovary preservation. We previously showed that long preservation of ovaries $(7 \mathrm{~h})$ under warm $\left(30^{\circ} \mathrm{C}\right)$ conditions impairs the developmental competence of the oocytes (Iwata et al. 2003). Furthermore, there is an efflux of ions, primarily K, from the cell before its death (Bortner et al. 1997, McCarthy \& Cotter 1997, Bortner \& Cidlowski 1999, James et al. 2000), and ion concentrations in FF change 
post-mortem (Knudsen et al. 1979). These results and the results of the present study indicate that ion concentrations measured in slaughterhouse-derived ovaries may not directly reflect those in vivo. However, measurement of the elemental contents in FF provides useful information for improving maturation conditions.

In this study, the $\mathrm{Na} / \mathrm{K}$ ratio was greater in LFF than in SFF. Knudsen et al. (1979) reported that the $\mathrm{K}$ concentration in porcine SFF is greater than that in LFF and the $\mathrm{Na} / \mathrm{K}$ ratio affected embryo development (Jin et al. 1994). However, in this study, the $\mathrm{Na} / \mathrm{K}$ ratio in the maturation medium did not affect either the developmental competence or the progression of nuclear maturation.

The concentration of $\mathrm{Mg}$ in FF $(2-2.3 \mathrm{mM})$ was found to be higher than that in the media generally used for maturation such as TCM-199 and SOF $(0.5-0.8 \mathrm{mM})$, but the Ca concentration in FF was not different from that in these media. Mg has important roles in mammalian cells. For example, it acts as a co-factor in enzymatic reactions, and induces meiotic maturation of Xenopus oocytes (Belle et al. 1986). Furthermore, low concentrations of divalent cations ( $\mathrm{Mg}$ and $\mathrm{Ca}$ ), inhibit the resumption of meiosis, and the inhibitory effect of low $\mathrm{Mg}$ concentration is greater than that of low Ca (Leibfreid \& First 1979, Jagiello et al. 1982). In the present study, low Mg and Ca concentrations in the IVM medium impaired developmental competence, but did not affect the progression of nuclear maturation. On the other hand, a high $\mathrm{Mg}$ concentration (2 mM) and high $\mathrm{Mg} / \mathrm{Ca}$ ratio (2:1) improves early embryo development because $\mathrm{Mg}$ regulates $\mathrm{Ca}$ homeostasis in zygotes (Lane et al. 1998). However, increasing $\mathrm{Mg}$ to $2 \mathrm{mM}$ from $0.5 \mathrm{mM}$ improved developmental competence and hastened the progression of nuclear maturation, irrespective of the Ca concentration. This indicates that the optimal Mg concentrations in IVM are probably higher than the concentrations in TCM-199 and SOF. However, it is unclear why $\mathrm{Mg}$ has a beneficial effect.

Glucose has been reported to be an essential energy substrate for maturation of bovine oocytes (Rieger \& Loskutoff 1994, Lim et al. 1999). And adding glucose to the culture medium enhanced glycolysis of oocytes, and a higher glycolysis rate in in vitro-maturated oocytes reflects a higher developmental competence (Krisher \& Bavister 1999). Cumulus and oocyte complexes metabolize glucose through glycolysis and the pentose phosphate pathway, and metabolites of glucose are thought to regulate meiotic maturation (Rose-Hellekant et al. 1995, Downs et al. 1996, Krisher \& Bavister 1999). The present results indicate that sufficient glucose is required for oocytes to obtain developmental competence during the maturation period, although the reason for the beneficial effect of high glucose concentration in maturation remains unclear.

The time required for oocytes to resume meiosis and progress to $\mathrm{M} 2$ arrest is closely associated with developmental competence of the oocytes (Dominko \& First 1997). However, little is known about the underlying causes of this relationship. On the other hand, when oocytes are inseminated shortly after M2 arrest, their developmental competence is very low (Johnston et al. 1986, Kubiak 1989). In this study, high Mg and glucose hastened the progression of nuclear maturation and improved the developmental competence of oocytes. However, prolonging the maturation period from 21 to $24 \mathrm{~h}$ did not change the rate of blastulation (Table 7 ). In addition, the rate of normal fertilization was the same between these experimental groups (data not shown). The present results, together with these previous results, indicate that the beneficial effects of high $\mathrm{Mg}$ and glucose in the IVM medium are due to their ability to speed up the progression of nuclear maturation.

Recently, Ali \& Sirard (2002) reported that during bovine oocyte maturation serum was successfully replaced with polyvinylpyrrolidone-40. In this study, we used serum as a protein source, which may change the final concentration of elements. To clearly understand the effects of ion concentration on oocyte maturation, further study is required with fully chemically defined conditions.

In conclusion, the progression of meiotic maturation is affected by the oocyte source (LFs are better than SFs), and by the $\mathrm{Mg}$ and glucose concentrations in the IVM medium. Furthermore, a fast progression of nuclear maturation is closely associated with the high developmental competence of oocytes.

\section{References}

Ali A \& Sirard MA 2002 Effect of the absence or presence of various protein supplements on further development of bovine oocytes during in vitro maturation. Biology of Reproduction 66 901-905.

Belle R, Mulner-Lorillon O, Marot J \& Ozon R 1986 A possible role for $\mathrm{Mg}^{2+}$ ions in the induction of meiotic maturation of Xenopus oocyte. Cell Differentiation 19 253-261.

Blondin P \& Sirard MA 1995 Oocyte and follicular morphology as determining characteristics for developmental competence in bovine oocytes. Molecular Reproduction and Development $\mathbf{4 1}$ $54-62$.

Blondin P, Coenen LA, Guilbault LA \& Sirard MA 1997 In vitro production and bovine embryos: developmental competence is acquired before maturation. Theriogenology 47 1061-1075.

Bortner CD \& Cidlowski JA 1999 Caspases independent/dependent regulation of $\mathrm{K}^{+}$, cell shrinkage, and mitochondria membrane potential during lymphocyte apoptosis. Journal of Biological Chemistry $27421953-21962$.

Bortner CD, Hughes FM Jr \& Cidlowski JA 1997 A primary role for $\mathrm{K}^{+}$and $\mathrm{Na}^{+}$efflux in the activation of apoptosis. Biological Chemistry 272 32436-32442.

Dieleman SJ, Hendriksen PJ, Viuff D, Thomsen PD, Hyttel P, Knijn HM, Wrenzycki C, Kruip TA, Niemann H, Gadella BM, Bevers MM \& Vos PL 2002 Effects of in vivo prematuration and in vivo final maturation on developmental capacity and quality of pre-implantation embryos. Theriogenology 57 5-20.

Dominko T \& First NL 1997 Timing of meiotic progression in bovine oocytes and its effect on early embryo development. Molecular Reproduction and Development 47 456-467.

Downs SM, Humpherson PG, Martin KL \& Leese HJ 1996 Glucose utilization during gonadotropin-induced meiotic maturation in cumulus cell-enclosed mouse oocytes. Molecular Reproduction and Development 44 121-131. 
Fair T, Hyttel P \& Greve T 1995 Bovine oocyte diameter in relation to maturational competence and transcriptional activity. Molecular Reproduction and Development 42 437-442.

Hagemann LJ 1999 Influence of the dominant follicle on oocytes from subordinate follicles. Theriogenology 51 449-459.

Hagemann LJ, Beaumont SE, Berg M, Donnison MJ, Ledgard A, Peterson AJ, Schurmann A \& Tervit HR 1999 Development during single IVP of bovine oocytes from dissected follicles: interactive effects of estrous cycle stage, follicle size and atresia. Molecular Reproduction and Development 53 451-458.

Hendriksen PJ, Vos PL, Steenweg WN, Bevers MM \& Dieleman SJ 2000 Bovine follicular development and its effect on the in vitro competence of oocytes. Theriogenology 53 11-20.

Iwata H, Ohota M, Hashimoto S \& Nagai Y 2003 Free oxygen radicals are generated at the time of aspiration of oocytes from ovaries that have been stored for a long time. Zygote 11 1-5.

Jagiello G, Ducayen MB, Downey R \& Jonassen A 1982 Alterations of mammalian oocyte meiosis I with divalent cations and calmodulin. Cell Calcium 3 153-162.

James R, Trimarchi JR, Liu L, Smith PJS \& Keefe DL 2000 Noninvasive measurement of potassium efflux as an early indicator of cell death in mouse embryos. Biology of Reproduction 63 851-857.

Jin Z, Jin M \& Roomans GM 1994 Effect of extracellular $\mathrm{K}^{+}$on hatching and outgrowth of mouse blastocysts in vitro. Cell Biology International 18 897-901.

Johnston LA, O'Brien SJ \& Wildt ED 1986 In vitro maturation and fertilization of domestic cat follicular oocytes. Gamete Research 24 343-356.

Knudsen JF, Litkowski LJ, Wilson TL, Guthrie HD \& Batta SK 1979 Follicular fluid electrolytes and osmolality in cyclic pigs. Journal of Reproduction and Fertility 57 419-422.

Krisher RL \& Bavister BD 1999 Enhanced glycolysis after maturation of bovine oocytes in vitro is associated with increased developmental competence. Molecular Reproduction and Development 53 19-26.

Kubiak JZ 1989 Mouse oocytes gradually develop the capacity for activation during the metaphase 2 arrest. Developmental Biology $136537-545$.

Lane M, Boatman DE, Albrecht RM \& Bavister BD 1998 Intracellular divalent cation homeostasis and developmental competence in the hamster preimplantation embryo. Molecular Reproduction and Development 50 443-450.
Leibfried L \& First NL 1979 Effects of divalent cations on in vitro maturation of bovine oocytes. Journal of Experimental Zoology $210575-580$.

Lim LM, Lee BC, Lee ES, Chung HM, Ko JJ, Park SE, Cha KY \& Hwang WS 1999 In vitro maturation and in vitro fertilization of bovine oocytes cultured in a chemically defined, protein-free medium: effect of carbohydrates and amino acids. Reproduction, Fertility, and Development 11 127-132.

Lonergan P, Monaghan P, Rizos D, Boland MP \& Gordon I 1994 Effect of follicle size on bovine oocyte quality and developmental competence following maturation, fertilization, and culture in vitro. Molecular Reproduction and Development 37 48-53.

McCarthy JV \& Cotter TG 1997 Cell shrinkage and apoptosis: a role for potassium and sodium efflux. Cell Death and Differentiation 4 $756-770$

Pavlok A, Lucas-Hahn A \& Niemann H 1992 Fertilization and developmental competence of bovine oocytes derived from different categories of antral follicles. Molecular Reproduction and Development 31 63-67.

Rieger D \& Loskutoff NM 1994 Changes in the metabolism of glucose, pyruvate, glutamine and glycine during maturation of cattle oocytes in vitro. Journal of Reproduction and Fertility $100257-$ 262.

Rose-Hellekant TA, Libersky-Williamson EA \& Bavister BD 1995 Energy substrates and amino acids provided during in vitro maturation of bovine oocytes alter acquisition of developmental competence. Zygote 6 285-294.

Takahashi Y \& First NL 1992 In vitro development of bovine one-cell embryos: influence of glucose, lactate, pyruvate, amino acids and vitamins. Theriogenology 37 963-978.

Yang X, Kubota C, Suzuki H, Taneja M, Bols PE \& Presicce GA 1998 Control of oocyte maturation in cows - biological factors. Theriogenology $49471-482$.

Received 4 August 2003

First decision 23 September 2003

Accepted 29 October 2003 